\title{
Human resources and innovative behaviour: Improving nursing performance
}

This study examines, using the Social Exchange Theory, the mediating effect of employees' perception of wellbeing on the relationship between two human resource management factors (satisfaction with teamwork and satisfaction with training opportunities) and innovative behaviour of nurses working in Australian public and private hospitals. Current nurse shortages and limited budgets have increased the need for hospitals to improve their efficiency and cost-effectiveness. It is proposed that fostering innovative behaviour is one way that hospitals can improve the efficiency and effectiveness of nurses. A cross-sectional self-report survey was completed by 220 nurses working within Australian hospitals. The results show that an employee's perception of their wellbeing completely mediated the relationship between satisfaction with training opportunities and their innovative behaviour, and partially mediated the relationship between satisfaction with teamwork and innovative behaviour. The findings shed new light on how human resource management factors can foster innovative behaviour. The results raise new implications for managers seeking to stimulate innovative behaviour, highlighting the importance of cultivating an organisational environment conducive to positive perceptions of wellbeing.

Keywords: Australia; innovative behaviour; human resources; wellbeing; nurses; Social Exchange Theory (SET)

\section{Introduction}

Spiralling demand and rising costs have made organisational efficiency a central concern for hospitals (Aiken et al. 2012). Cost containment strategies have contributed to increased nursing workloads and to a perceived worsening of working conditions (Aiken et al. 2012). Inadequate nursing work environments have been linked to reduced quality of patient care; increased job dissatisfaction among nurses; increased incidence of nurse burnout; and elevated intention to quit current nursing employment (e.g., Aitken et. al., 2013; DeKeyser-Ganz \& Torren, 2013; Toh et al. 2012; Twigg, Duffield, Thompson, \& Rapley, 2010). 
Nursing shortages now exist in many countries around the world (Buchan, 2002; Maclean, Hassmiller, Shaffer, Rohrbaugh, Collier, \& Fairman, 2014). Worsening shortages loom in OECD countries (OECD, 2006) including Australia (Health Workforce Australia, 2012; Duffield, Roche, O’Brien-Pallas, Catling-Paull, \& King 2009; McMurray \& Williams, 2004). Australia faces an estimated shortfall of 109,490 nurses by 2025 (Health Workforce Australia, 2012). Fostering organisational innovation is one method to drive organisational competitiveness (Naranjo-Valencia, JiménezJiménez, \& Sanz-Valle, 2011). Organisational efficiency and effectiveness can be improved by increasing the innovative behaviour of employees (Carmeli, Meitar and Weisberg 2006; Scozzi, Carvelli and Crowston 2005). Developing the innovative behaviour of nurses is one way that hospitals can work with reduced budgets and do more with less (Åmo, 2006).

In Australian hospitals nurse unit managers have been increasingly expected to foster teamwork and innovative behaviour (McCallin \& Frankson, 2010; McMurray \& Williams, 2004). However, there has been very little research into factors potentially influencing the innovative behaviour of nurses (e.g. Åmo, 2006; Knol \& van Linge, 2009; Reuvers, van Engen, Vinkenburg, \& Wilson-Evered, 2008). Given the escalation of nursing capacity shortages in Australia (Health Workforce Australia, 2012), and much of the world (OECD, 2006; Maclean et al, 2014), research into factors influencing nurses' innovative behaviour is relevant to hospital managers facing cost constraints and nursing capacity shortages.

A growing body of research indicates that HR factors affect employee creativity and innovative behaviour (Jimenez-Jimenez and Sanz-Valle, 2005; Jiang, Wang, \& Zhao, 2012). For instance, studies have shown that new knowledge aids innovative behaviour (Maqsood, Walker, \& Finegan, 2007; Xerri \& Brunetto, 2011); that 
teamwork influences employee creativity (Jiang et al, 2012). Research indicates that HR factors can affect employee psychological wellbeing (Guest, 2011; Kooij et al., 2013) and that psychological wellbeing is linked to creativity (Van Dyne et al., 2002, Wright \& Walton, 2003).

Kinnie, Hutchinson, Purcell, Rayton, and Swart (2005) argue that the attitudes of employees towards HRM are important because attitudes drive discretionary behaviour, such as innovative behaviour. However, only a few studies (e.g., Sanders, Moorkamp, Torka, Groeneveld, \& Groeneveld, 2010; Veenendaal \& Bondarouk, 2015; Zhou, Zhang, \& Montoro-Sánchez, 2011) have examined links between employee attitudes about human resource (HR) factors and the innovative behaviour of employees.

Following Gould-Williams and Davies (2005), we conceptualise teamwork and training as two important high commitment HRM functions that shape employee attitude and influence exchanges between employees and the organisation. In particular, using the theoretical lens of Social Exchange Theory (SET) we explore how HR related workplace exchange among nurses (e.g., satisfaction with teamwork), and between nurses and the organisation (e.g., satisfaction with training opportunities), influences psychological wellbeing and the innovative behaviour of nurses. The rationale for examining satisfaction with teamwork and satisfaction with training opportunities, as opposed to outcomes such as productive output and learning or behaviour change, is to gain insights into the effect of these high commitment HR factors as components of the social exchange between nurses and the organisation. 


\section{Literature}

\section{Social Exchange Theory}

In the seminal work, "exchange and social life", Blau (1964) conceived relationships as social associations that take the form of 'an exchange activity, tangible or intangible, and more or less rewarding or costly, between at least two persons' (p.88). In the workplace, one party (i.e., the organisation, a supervisor or colleague) can provide another party (i.e., the employee) with various forms of benefit (e.g., training opportunities, access to resources, support); when the receiver deems the benefit is both valuable (Homans, 1974) and equitable (Carrell \& Dittrich, 1978), they will likely feel obligated to reciprocate in some way.

Hannah and Iverson (2004) propose that employees see HR practices as the organisation's personal commitment to them. Gong, Law, Chang, and Xin (2009) and Morrison (1996) assert that HR practices represent a form of exchange, whereby benefits received through organisational $\mathrm{HR}$ practices leave the employee feeling obligated to reciprocate (e.g., with commitment to the organisation). Noblett and Rodwell (2009) suggest that employees evaluate the equity of the exchange by comparing their inputs and outputs with those of their colleagues; and only if each party perceives equity in relation to the exchanges does a reciprocal relationship arise wherein each feels indebted to the other. Furthermore, Noblett and Rodwell (2009) found that feelings of inequity or unfairness in relation to a social exchange can negatively influence employee wellbeing; so the employee's perception of benefits received may result in feeling more or less satisfied (i.e., higher or lower wellbeing) and more or less inclined to reciprocate.

SET provides a sound theoretical framework for the study of innovative 
behaviour by employees. Innovative behaviour constitutes an extra-role performed in addition to expected daily work tasks expected of an employee (Xerri, 2014). For nurses, innovative behaviour is viewed as discretionary behaviour (Sanders et al., 2010); it is seen as an 'extra-role' performed in addition to the expected daily work tasks (Xerri, 2014). The innovative behaviour of nurses may be seen as a product of the social exchange between the hospital organisation and its nursing employees, constituting a form of reciprocation for benefits received through HR practices.

Teamwork and training are integral to nursing practice, and are significant components of HRM practice in hospitals. In this study, we examine if nurses perceived satisfaction with teamwork and training opportunities create a positively contributes to psychological wellbeing, and influences willingness to reciprocate with innovative behaviour

\section{Innovative behaviour}

Innovative behaviour refers to the process by which an employee solves a work-based problem. Typically, the individual recognises a problem, generates ideas or solutions, and then seeks to mobilise support from others to implement them (Scott \& Bruce, 1994). Organisational innovation has been described as '...the intentional introduction and application within a job, work team, or organization of ideas, processes, products, or procedures, which are new... and which are designed to benefit the job, the work team, or the organisation' (West \& Farr, 1990, p. 9). Within organisations, innovation occurs when innovative behaviour leads to change "which is regarded as new by the relevant unit of adoption and through which change is brought about" (Martins \& Treblanche, 2003, p. 67). In nursing, innovative behaviour is "the "practical application" of new ideas in an effective manner' in conformity with organisational objectives 
(McMurray and Williams, 2004, p.349).

The organisational context affects the micro process of innovation within organisations (Kanter 1996, Tidd \& Bessant 2013). HR factors shape the organisational context and research evidences linkages between HRM and innovative behaviour. For instance: a study by Jimènez-Jimènez and Sanz-Valle (2005) identified a fit between HR practices (including team working, long-term and skill-oriented staffing, extensiveand long-term oriented training) and organisational innovation; and another study by Zhou et al. (2011) identified a relationship between HR rewards management and innovative behaviour.

However as Sanders et al. (2010) suggest, links between HR factors and employee behaviour are logically subject to employee perception: "To exert their desired effect on employee behaviour, HR practices first have to be perceived and interpreted by employees in ways that will engender behavioural reactions" (p. 59). However, only a few studies have examined links between employee perceptions of specific HR factors and innovative workplace behaviour (Veenendaal \& Bondarouk, 2015).

In a study of employees in Dutch and German technical organisations, satisfaction with HR practices was found to mediate the relationship between leadermember exchange (LMX) and innovative behaviour (Sanders et al., 2010). In a study of managerial employees in Indian service sector organisations, work engagement was found to be positively related to innovative behaviour, and that work engagement mediated the relationship between LMX and innovative behaviour (Argwal et al., 2012). A study of nurses in acute healthcare settings found that innovative behaviour was supported by structural and psychological empowerment; and that psychological 
empowerment mediated the link between structural empowerment and innovative behaviour (Knol \& van Linge, 2009).

Veenendall and Bondarouk (2015) examined innovative work behaviour (IWB) as a multidimensional construct comprising idea generation, idea championing and idea application; and they investigated employee perceptions of four high commitment HR practices (supportive supervision, training and development opportunities, information sharing and fair compensation) on these dimensions of IWB among production employees in a Dutch manufacturing company. Overall, their results supported the proposition that employee perception of specific HR practices influenced various dimensions of IWB (Veenendaal \& Bondarouk, 2015), although the effects of particular HR practices were mixed. In particular, although supportive supervision was positively associated with all three IWB dimensions and information sharing was positively associated with idea generation and idea application, training and development opportunity was negatively associated with idea generation, and fair compensation was negatively associated with all three dimensions of IWB.

\section{Psychological wellbeing}

Wellbeing can be described as the overall quality of an employee's experience and functioning at work, embodying the physical, mental and emotional aspects of employee health (DeJoy \& Wilson, 2003). Past literature outlines three dimensions of wellbeing: 1) psychological (agency, satisfaction, self-respect, and capabilities), 2) physical (nourishment, shelter, health care, clothing, and mobility), and 3) social (community participation, public acceptance, and helping others) (Grant, Christianson, \& Price, 2007).

Psychological wellbeing is the focus of concern in this study. Although social and physical wellbeing may play a role in fostering innovative behaviour, in this study 
the central issue is how employees' perception of their own wellbeing affects their willingness to be innovative. In particular, psychological wellbeing is used to ascertain employee perceptions of overall wellbeing; and we examine how wellbeing is affected by satisfaction with training opportunities and teamwork.

Psychological wellbeing refers to an employee's perception and attitude toward their overall work environment (Diener, 2000). Psychological wellbeing is subjective so employees' are psychologically well as long as they perceive themselves to be well (Wright, Cropanzano, \& Bonett, 2007). Wright et al. (2007) suggest that "happiness" is a way to describe psychological wellbeing. Employees high in psychological wellbeing exhibit noticeable positive affect and an absence of negative affect (Myers \& Diener, 1995).

Some studies have examined how certain factors associated with a lack of wellbeing affect innovative behaviour. For example, burnout (Huhtala \& Parzefall, 2007) and emotional exhaustion (Cropanzano, Rupp, \& Byrne, 2003) have been negatively associated with employee innovative behaviour. Low job satisfaction and burnout are endemic in nursing (Aiken et al., 2001, Chang, Ma, Chiu, Lin, \& Lee, 2009). Low job satisfaction has been associated with reduced productivity and higher turnover among nurses (Shader, Broome, Broome, West, \& Nash, 2001; Bartram, Joiner, \& Stanton, 2004).

Although researchers have established the link between wellbeing and creativity (Van Dyne et al., 2002, Wright \& Walton, 2003), the relationship between psychological wellbeing and innovative behaviour has not yet been examined. Consequently, this study tests the proposition that higher levels of wellbeing will be positively associated with innovative behaviour. 
Hypothesis 1: Employee perception of wellbeing will be positively correlated with their perceived level of innovative behaviour

\section{Satisfaction with teamwork}

In an organisational context, a team is a group of employees formed with an intention to attain a common goal or execute a particular task (Katzenbach \& Smith, 1993). Teamwork is an essential feature of nursing practice in Australian hospitals (McMurray \& Williams, 2004; Nelsey \& Brownie 2012), so much so that nursing can be viewed as "teamwork that is focused on achieving safe outcomes for patients and nurses" (Nelsey \& Brownie, 2012, p. 199). In this study, we examine an employee's satisfaction with teamwork, which we conceptualise as being unique to other forms teamwork measurement, for example, teamwork effectiveness (Judeh, 2011), performance or level of team interaction (Lim \& Klein, 2006). Satisfaction with teamwork specifically examines an employee's perception of their general exchange with other team members; that is, benefits will be exchanged as part of teamwork and over time it is these benefits that form a reciprocal relationship between team members. Furthermore, such reciprocation may also benefit the organisation (Gould-Williams and Davies, 2005).

Effective teams are thought to contribute positively to individual and organisational performance. In nursing contexts, research indicates that dysfunctional teams inhibit work performance, lower productivity and reduce job satisfaction; and effective teams lift job satisfaction and increase nurse retention (Carver \& Candela, 2008; Duffield, Roche, O’Brien-Pallas, Catling-Paull, \& King , 2009; Nelsey \& Brownie, 2012). Self-managing teamwork (van Mierlo et al., 2005) and group autonomy (van Mierlo et al., 2001) have been positively linked with psychological wellbeing. Shader et al. (2001) found a positive relationship between group cohesion 
and work satisfaction in nursing. Kalisch, Hyunhwa and Rochman (2010) found that higher levels of satisfaction with occupation and current position were reported when nurses rated their teamwork more highly.

Teambuilding activities have been associated with higher levels of job satisfaction in nursing (Amos, Hu, \& Henrick, 2005). DiMeglio et al. (2005) found that team building activities produced greater group cohesion and higher job satisfaction among nursing teams. Nevertheless, there has been very little examination of possible links between satisfaction with teamwork and psychological wellbeing. Self-managing teamwork (van Mierlo, Rutte, Kompier, \& Doorewaard, 2005) and group autonomy (van Mierlo , Rutte, Seinen, \& Kompier, 2001) have been positively linked with psychological wellbeing; and prior research identifies that employees who work in teams enjoy higher levels of wellbeing than those who do not (Carter, 2000; Wallin \& Wright, 1986). However, except for one study by Brunetto et al. (2011a), the specific link between perceived satisfaction with teamwork and psychological wellbeing has not been investigated in research. The present study adds to current evidence by testing the postulate that satisfaction with teamwork is positively related to psychological wellbeing.

Hypothesis 2: Employee satisfaction with teamwork will be positively correlated with their perception of psychological wellbeing.

Effective teamwork is commonly considered an important condition for organisational innovation (e.g., Kanter 1996; Martins \& Treblanche, 2003; Tidd \& Bessant, 2013). The conventional wisdom is that effective teamwork aids organisational 
innovation by fostering trust and information exchange (e.g., Arad, Hanson, \& Schneider, 1997; Hiltrop, 1996).

In healthcare, effective teamwork is said to support information exchange, learning and professional development (e.g., Sargeant, Loney, \& Murphy, 2008; Nelsey \& Brownie, 2012); and effective nursing teams are said to aid learning by enabling nurses to "explore contemporary and/or different work practices and to challenge their own assumptions and attitudes' (Nelsey and Brownie, 2012, p. 199).

According to Cox $(2001,2003)$, positive workgroup outcomes such as creativity and innovation are more likely to arise in functional teamwork environments, rather than those characterised by substantial intragroup conflict. West and Wallace (1991) found that team commitment (i.e., a desire to maintain membership, belief in, and acceptance of the values and goals of the team, and a willingness to exert effort for the team) was a significant predictor of innovation in UK primary healthcare teams. As well, past empirical research evidences links between effective teamwork and innovation in healthcare settings; specifically, in a study of UK primary healthcare teams (comprising doctors, nurses and health visitors) West and Wallace (1991) identified a positive relationship between teamwork (team collaboration, group cohesion, team commitment and climate) and practice innovativeness. However, research has so far overlooked the possibility of a link between satisfaction with teamwork and perceived innovative behaviour.

Based on the underlying notions of SET, employees may reciprocate the benefits arising from satisfying teamwork by attempts to be more innovative in the workplace. Consequently, in this study we test the proposition that satisfaction with teamwork will be positively associated with perceived innovative behaviour. 
Hypothesis 3: $\quad$ Employee satisfaction with teamwork will be positively correlated with their perceived level of innovative behaviour.

\section{Satisfaction with training opportunities}

Within organisations, training is a set of planned activities that enable employees to gain new skills, knowledge and expertise relevant to their job (van Eijs \& Heijke, 2000). In this study, we examine an employee's satisfaction with training opportunities, which is distinguished from other forms of training measurement (e.g., learning outcomes, behaviour change, and outcome of behaviours) (Kirkpatrick, 1979). Satisfaction with training opportunities is relevant to an employee's perception of their general exchange with the organisation; specifically, if an employee is satisfied with the training benefits they receive (i.e., training opportunities), a reciprocal relationship arises between the employee and the organisation.

Santos and Stuart (2003) posit that employee perceptions of training opportunities may relate to factors such as employee engagement and organisational commitment; and they point to the need for research into possible links between employees' perceptions of training opportunities and employees' attitudes in the workplace. Brunetto, Farr-Wharton and Shacklock (2012) found that private sector nurses' satisfaction with training and development is a predictor of perceived wellbeing. However, studies indicate that there may be important differences between private and public sector nurses (Brunetto et al., 2016) and the link between perceived training opportunities and wellbeing is yet to be tested on a combination of public and private sector nurses. Testing the relationship between satisfaction with training and psychological wellbeing across a combined sample of private and public sector nurses 
can help to determine if the previous results (Brunetto et al, 2012) are representative of nurses working in public and private hospitals in Australia.

Hypothesis 4: Employee satisfaction with training opportunities will be positively correlated with their perceived level of psychological wellbeing.

Extant research provides a confusing picture of the relationship between training and innovation. A study of 225 dyads in Fortune 500 manufacturing plants found that members in higher quality dyads were more likely to be innovative, suggesting that innovative behaviour could be lifted by training managers to initiate better exchanges with followers (Basu and Green, 1997). An examination of data from 152 Spanish companies found a positive relationship between the stock of qualified human capital and the accumulative nature of innovation; however, the result was not strong enough to confirm the hypothesis that possession of superior human resources increased the accumulative innovation activity (Galende and Fuente, 2003).

The link between satisfaction with training opportunities and perceived innovative behaviour has received little attention in research. However, in one study of 328 workers in a Dutch manufacturing company it was found that employees' perception of training and development opportunity was negatively associated with the idea generation component of innovative work behaviour (Veenandaal and Bondarouk (2015). It is logical to anticipate that an employee's perception of training opportunities may have some association with perceived innovative behaviour. SET can be used to explain why such a relationship is feasible. In particular, training can develop competencies that enable innovative solutions to workplace problems; a furthermore, 
favourable perception of training opportunities constitutes a benefit in the exchange relationship and this increases the likelihood that an employee will reciprocate by enacting innovative workplace behaviour.

Hypothesis 5: Employee perception of training opportunities will be positively correlated with their perceived level of innovative behaviour.

\section{Wellbeing as mediating factor}

There exists empirical support for the connection between HR practices and employee wellbeing. In particular, Wood and de Menezes (2011) examined four dimensions of High Performance Work Systems (enriched jobs, high involvement management, employee voice, and economic involvement) and found that enriched jobs were positively associated with higher perceived wellbeing (job satisfaction and anxietycontentment).

Following the principles of reciprocity set out by Gouldner (1960), we posit the possibility of psychological wellbeing as a mediating factor. That is, if an employee is satisfied with the teamwork and training opportunities encountered, the employee will be more likely to enjoy higher psychological wellbeing; and an employee that enjoys higher psychological wellbeing will be more inclined to reciprocate by attempting innovative workplace behaviour. Teamwork will be satisfying when the employee perceives that organisational teamwork practices facilitate access to support that enables innovative behaviour; and training opportunities will be satisfying when the employee perceives that the offered training supports the acquisition of competencies enabling innovative behaviour (Maqsood et al., 2007; Xerri \& Brunetto, 2011). In the present study we test: 
Hypothesis 6: Employee perception of wellbeing will mediate the relationship between employee perception of training opportunities and their perceived level of innovative workplace behaviour.

Hypothesis 7: Employee perception of wellbeing will mediate the relationship between employee perception of teamwork and their perceived level of innovative workplace behaviour.

Insert Figure 1 about here

\section{Methods}

\section{Measures}

Scott and Bruce's (1994) measure of employee innovative behaviour was used to examine nursing employees' perception of their innovative behaviour in the workplace. As an example, 'I create new ideas for difficult issues'. This scale produced a high level of internal consistency with an Average Variance Extracted (AVE) of 0.57 and composite reliability of 0.78 .

Satisfaction with teamwork was measured using Rubin, Palmgreen, Sypher, and Beatty's (1994) version of an organisational culture survey developed by Glaser, Zamanou and Hacker (1987). An example of a sample item is: "people I work with are cooperative and considerate'. The scale possessed an adequate level of internal consistency, with an AVE of 0.65 and composite reliability equalling 0.87 . 
The training and development scale asked about nurses' satisfaction with training and options for career and skill development, using six items taken from Meyer and Smith's (2000) validated test bank. For example, 'I am happy with the training opportunities provided for me in this hospital'. The scale evidenced a high level of internal consistency, with AVE equalling 0.63 and composite reliability being 0.87 .

A construct to measure the psychological wellbeing of nurses was developed by Brunetto, Farr-Wharton, \& Shacklock (2011b), which they define as employees' attitudes and feelings about the work context. An example sample item is: 'Overall, I am reasonably happy with my work-life'. The scale provided an adequate level of internal consistency, yielding an AVE of 0.61 and measuring composite reliability of 0.87 .

\section{Sample}

The sample included private $(\mathrm{n}=104)$ and public $(\mathrm{n}=106)$ sector nurses working in public and private hospitals in Australia. There were 187 females (89\%) and 23 males $(11 \%)$ in the sample. The respondents included $111(52.9 \%)$ nurses aged 45 years or over, $70(33.3 \%)$ aged between 31 and 44, and $27(12.9 \%)$ aged 30 years or less. Regarding education, 47 (22.4\%) respondents were hospital trained, 45 (21.4\%) were trained in a technical institution (e.g., vocational education programs), and 118 (56.2\%) were trained in universities. Of those that were university trained, 86 (41\%) held an undergraduate degree and $32(15.2 \%)$ held a postgraduate degree.

\section{Data analysis}

The Statistical Package for Social Sciences (SPSS) v.21 was used for the descriptive analyses. Analysis of Moment Squares (AMOS) v.21 was used to test all of the hypotheses and to check for common method bias. The two-step approach to Structural 
Equation Modelling (SEM) prescribed by Anderson and Gerbing (1988) was applied to test the hypotheses. To test the mediation hypotheses the bootstrap approach was employed (MacKinnon, Lockwood, Hoffman, West, \& Sheets, 2002; MacKinnon, Lockwood, \& Williams, 2004); this method was used because it is considered to be more robust than other methods. The following fit indices were used to test model-fit: normed chi-square (chi-square/degrees of freedom or $\chi^{2} / \mathrm{df}$ ), wherein range should be from 1 to $3, \mathrm{CFI}$ and TLI $\geq 0.90$ for an adequate fit and $\geq 0.95$ for a superior fit (Byrne, 2010), RMSEA $<0.08$ for an adequate fit and $<0.05$ for a good fit (Browne \& Cudeck, 1993), and the SRMR indicating a good fitting model when $<0.10$ (Kline, 2011).

The results from the descriptive statistics (see Table 1) and SEM analysis (see Table 3) indicated no concerns in relation to reliability or validity. Composite reliability for each variable was calculated to examine internal consistency, and all variables satisfied the required cut-off value of 0.7 (Hair, Black, Babin, \& Anderson, 2010). The AVE was used to check validity, and all calculated AVEs satisfied the necessary standard of $>0.5$ (Hair et al., 2010). Furthermore, all observed variables loaded appropriately onto their respective factors (exceeding 0.70) and there was an absence of cross-loadings. Additionally, the square root of the combined AVE for each construct was greater than the associated inter-correlation (see Table 2) (Hair et al., 2010). Finally, due to the cross-sectional nature of the data used, a common latent factor (i.e., a dummy latent variable is added to the model to capture the common variance for all observed items) was added to the structural model to test for any common method bias issues (Podsakoff, MacKenzie, Lee, \& Podsakoff, 2003).

Insert Table 1 about here 
Due to reported differences between public and private sector nurses (Brunetto et al., 2016), an ANOVA was used to identify any statistically significant differences between the public and private sector nurses, including all the variables in the study. To conduct the ANOVA, it was important to first establish that the Levene's test had not been violated (see Table 2). The results from the ANOVA indicated that there were no statistically significant mean differences for any of the latent variables in the data collected from private and public sector nurses, providing statistical support that the data from both groups could be combined into a larger single sample more suitable for covariance-based SEM.

Insert Table 2 about here

\section{Results}

\section{Confirmatory factor analysis}

The initial result from the confirmatory factor analysis (CFA) indicated a good fit $\left(\chi^{2} / \mathrm{df}\right.$ $=1.89, \mathrm{CFI}=.935, \mathrm{TLI}=.926, \mathrm{RMSEA}=.055)$. However, one teamwork item recorded a squared multiple correlation below 0.1 , 'people I work with constructively confront problems'; and the removal of this item improved model fit $\left(\chi^{2} / \mathrm{df}=1.62, \mathrm{CFI}\right.$ $=.956, \mathrm{TLI}=.950, \mathrm{RMSEA}=.045)$.

Two structural models were compared to the hypothesised structural model. The results (Table 3) indicated that the full mediation model (Model 3), which included all the hypothesised paths, fitted the data slightly better than the two partial mediation models (Model 1 and 2). The results from a chi-square difference test (Byrne, 2010) indicated that Model 3 was statistically distinct from Models 1 and 2. Testing of Model 
4 also indicated that common method variance was of little concern; for example, the addition of a common latent factor to Model 3 still yielded a good model-fit, with all hypothesised paths remaining significant. However, to control for the impact of common method bias, Model 4 will be used to test the hypotheses.

Insert Table 3 about here

\section{Testing the hypotheses}

Figure 1 depicts the SEM results, which support acceptance of all hypotheses, aside from Hypothesis 4. Three structural models were examined to test Hypothesis 6 (wellbeing mediates the relationship between satisfaction with teamwork and innovative behaviour) and Hypothesis 7 (wellbeing mediates the relationship between perceived training opportunities and innovative behaviour): Model 1 being a partial mediation model, with wellbeing completely mediating the relationship between satisfaction with teamwork and innovative behaviour, while still partially mediating the relationship between training opportunities and innovative behaviour; Model 2 being another partially mediated model, with wellbeing completely mediating the relationship between satisfaction with training opportunities and innovative behaviour, while still partially mediating the relationship between satisfaction with teamwork and innovative behaviour; and Model 3 being a full mediation model, with wellbeing completely mediating both relationships between the two HR practices and innovative behaviour. 
The test for mediation involved first establishing a direct significant path from satisfaction with teamwork and training opportunities to innovative behaviour (with the mediator). As shown in Table 4, both relationships were found to be significant. However, the addition of the mediating variable (wellbeing) resulted in the relationship between satisfaction with training opportunities and innovative behaviour being rendered insignificant; so there is support for the acceptance of Hypotheses 6 and 7. Specifically, the results evident a significant indirect path from satisfaction with teamwork to innovative behaviour $(\beta=0.095, \mathrm{p}<0.05)$, which indicates that psychological wellbeing partially mediates the relationship between perceived satisfaction with teamwork and the perceived innovative behaviour of nursing employees. There is also a significant indirect path from perceived satisfaction with training opportunities to perceived innovative behaviour $(\beta=0.109, \mathrm{p}<0.05)$; and as this path is no longer significant with the addition of wellbeing, the results indicate that psychological wellbeing fully mediates the relationship between perceived satisfaction with training opportunities and the perceived innovative behaviour of nursing employees.

Insert Table 4 about here

\section{Concluding Discussion}

This study examined the relationship between satisfaction with two HR practices (teamwork and training), wellbeing and innovative behaviour in the workplace by testing for links between perceived innovative behaviour, psychological wellbeing and satisfaction with training opportunities and teamwork. The results confirm the 
importance of psychological wellbeing in the relationship between these two high commitment HR practices and perceived innovative behaviour.

In particular, the results show that psychological wellbeing fully mediates the relationship between satisfaction with training opportunities and perceived innovative behaviour; and the results also show that perceived psychological wellbeing partially mediates the relationship between satisfaction with teamwork and the perceived innovative behaviour of nursing employees. These findings advance current understanding by addressing previously untested relationships and bring significant implications for HR practices in nursing contexts.

Challenging working conditions evidently exist in nursing; and job stress and inadequate staffing are associated with lower levels of workplace productivity, job satisfaction and retention (Letvack \& Buck, 2008). The results of this study show that satisfying training and teamwork can contribute to higher psychological wellbeing, and in turn to innovative workplace behaviour. When training and teamwork are perceived as satisfying, nursing employees will enjoy higher psychological wellbeing and will be more likely to reciprocate by attempting be innovative in the workplace.

There exists some empirical support for a connection between HR practices and psychological wellbeing (Wood and de Menezes, 2011). Additionally, there exists some research support that satisfaction with HR practices can encourage innovative behaviour: in particular, satisfaction with HR practices has been related to positive employee attitudes such as affective commitment (Kinnie et al., 2005); and it has been shown that committed employees are more likely to reciprocate with actions that support attainment of beneficial organisational outcomes, such as innovative workplace behaviour (Xerri \& Brunetto, 2013). 
The results of this study indicate that when nurses report satisfaction with training and teamwork they report higher levels of psychological wellbeing and greater effort to be innovative in the workplace. In previous empirical work, Brunetto, FarrWharton and Shacklock (2012) found that private sector nurses' satisfaction with training and development was a predictor of perceived wellbeing. The current study strengthens and extends this finding. In particular, the results indicate that satisfying training opportunities contribute to the psychological wellbeing of nurses in both public and private hospital settings.

Furthermore, the results highlight the importance of psychological wellbeing as a factor supporting innovative behaviour. As psychological wellbeing fully mediates the relationship between satisfaction with training and perceived innovative behaviour, it can be anticipated that training will have little effect on innovative behaviour if psychological wellbeing is low. Intriguingly, Veenendall and Bondarouk (2015) found a negative relationship between satisfaction with training and innovative behaviour. Our findings indicate low psychological wellbeing as a plausible explanation. In particular, the results of this study indicate that even satisfying training may not inspire the discretionary effort for innovative workplace behaviour if other factors are negatively influencing wellbeing.

Cox $(2001,2003)$ asserts that creativity and innovation are more likely when effective teamwork exists; and past empirical research indicates that effective teamwork is associated with beneficial workplace outcomes including increased job satisfaction (e.g., Kalich et al., 2010) and innovation in healthcare settings (West \& Wallace, 1991). However, until now the relationship between satisfaction with teamwork and perceived innovative behaviour has not been empirically examined in research. The results of this 
study show that nurses' satisfaction with teamwork is associated with perceived innovative behaviour through the mediating variable of psychological wellbeing.

Notably, the results of this study add an important dimension to the relationship between teamwork and innovative behaviour, by highlighting that satisfaction with teamwork positively contributes to employee psychological wellbeing, which in turn supports the discretionary 'extra-role' (Xerri, 2014) of innovative behaviour. The finding is practically significant given the centrality of teamwork in modern nursing practice (e.g., Cox, 2003; Sargeant et al., 2008; Nelsey \& Brownie, 2012).

The partial mediation result is noteworthy in that it indicates more complex relationships between satisfaction with teamwork and perceived innovative behaviour. The results call for further investigation of other factors potentially affecting the relationship between satisfaction with teamwork and innovative workplace behaviour. That is, it seems that satisfying teamwork may support innovative behaviour through other (untested) pathways as well. Here, we can only speculate: perhaps satisfying teamwork could enable innovation by enhancing cohesion and commitment, or collaboration and knowledge sharing. Interestingly, effective teams have been linked to innovative behaviour in mixed healthcare teams (West \& Wallace, 1991); and Leggat (2007) has suggested that management training of clinician leaders could help leaders' foster commitment and psychological safety needed for improved healthcare team outcomes. There is scope for further research along these and other lines.

The results have practical implications for HRM in nursing contexts and for the broader context of fostering innovation, as far as innovative behaviour is concerned. The main implication is that innovative workplace behaviour will be more likely to arise when satisfying teamwork and high psychological wellbeing are both present. Consequently, in attempting to stimulate workplace innovation HR managers need to 
consider employees' satisfaction with training and teamwork. Furthermore, the results that low psychological wellbeing may stymie efforts to foster innovative behaviour.

Given the escalating shortages of staff capacity in nursing workplaces around the world (Buchan, 2002 ; Maclean et al, 2014), and the endemic problems of job dissatisfaction, burnout and falling retention (e.g. Aitken et. al., 2013; DeKeyser-Ganz \& Torren, 2013 ; Toh et al. 2012), HR managers and the line managers responsible for the implementation of HR practices in nursing workplaces need to pay more heed to nurses' psychological wellbeing in the design, implementation and evaluation of HR practices pertaining to training and teamwork. The results generally add to others' calls (e.g. Letvak \& Buck, 2008; McCallin \& Frankson, 2010; Nelsey \& Brownie 2012) for further research into HR factors affecting nurses' wellbeing, and particularly in regard to the relationship between satisfying teamwork wellbeing and innovative behaviour.

\section{Limitations}

This study contains a number of limitations that should be considered. There is general consensus that the modification of a structural model to increase model-fit may yield results that are sample specific (Byrne, 2010). One approach to overcome the limitation of modifying the model is to cross-validate the results, however, in this case the sample size was too small for cross-validation, and thus the modification remains a limitation. The limitation could be addressed by cross-validation or conducting further studies with larger samples. Another limitation is the cross-sectional nature of the data, which makes the results less generalizable; in this respect, longitudinal studies could ultimately establish theoretical validity in nursing contexts. 


\section{References}

Aiken, L. H., Clarke, S. P., Sloane, D. M., Sochalski, J. A., Busse, R., Clarke, H., . . Shamian, J. (2001). Nurses' Reports on Hospital Care in Five Countries. Health Affairs, 20(3), 43-53. doi: 10.1377/hlthaff.20.3.43

Aiken, L. H., Sermeus, W., Van den Heede, K., Sloane, D. M., Busse, R., McKee, M., . . Moreno-Casbas, M. T. (2012). Patient safety, satisfaction, and quality of hospital care: cross sectional surveys of nurses and patients in 12 countries in Europe and the United States. British Medical Journal (BMJ), 344, 1-14.

Åmo, B. (2006). Employee innovation behaviour in health care: the influence from management and colleagues. International Nursing Review, 53(3), 231-237. doi: 10.1111/j.1466-7657.2006.00455.x

Amos, M. A., Hu, J., \& Herrick, C. A. (2005). The impact of team building on communication and job satisfaction of nursing staff. Journal for Nurses in Professional Development, 21(1), 10-16. Retreived from http://www.ncbi.nlm.nih.gov/pubmed/15731637

Anderson, J. C., \& Gerbing, D. W. (1988). Structural equation modeling in practice: A review and recommended two-step approach. Psychological Bulletin, 103(3), 411-423. doi: 10.1037/0033-2909.103.3.411

Arad, S., Hanson, M. A., \& Schneider, R. J. (1997). A framework for the study of relationships between organizational characteristics and organizational innovation. Journal of Creative Behavior, 31(1), 42-58.

Agarwal, U. A., Datta, S., Blake-Beard, S., \& Bhargava, S. (2012). Linking LMX, innovative work behaviour and turnover intentions: The mediating role of work engagement. Career Development International, 17(3), 208-230. doi: $10.1108 / 13620431211241063$

Bartram, T., Joiner, T. A., \& Stanton, P. (2004). Factors affecting the job stress and job satisfaction of Australian nurses: Implications for recruitment and retention. Contemporary Nurse, 17(3), 293-304.

Basu, R., \& Green, S. G. (1997). Leader-Member Exchange and Transformational Leadership: An Empirical Examination of Innovative Behaviors in LeaderMember Dyads. Journal of Applied Social Psychology, 27(6), 477-499. doi: 10.1111/j.1559-1816.1997.tb00643.x

Blau, P. (1964). Exchange and power in social life. New York: Wiley.

Browne, M. W., \& Cudeck, R. (1993). Alternative ways of assessing model fit. Sociological Methods \& Research, 21(2), 230-258. doi: 10.1177/0049124192021002005

Brunetto, Y., Farr-Wharton, R., \& Shacklock, K. (2011a). Supervisor-nurse relationships, teamwork, role ambiguity and well-being: Public versus private sector nurses. Asia Pacific Journal of Human Resources, 49(2), 143-164. doi: 10.1177/1038411111400161

Brunetto, Y., Farr-Wharton, R., \& Shacklock, K. (2011b). Using the Harvard HRM model to conceptualise the impact of changes to supervision upon HRM outcomes for different types of public sector employees International Journal of Human Resource Management, 22(3), 553-573. doi:10.1080/09585192.2011.543633

Brunetto, Y., Farr-Wharton, R., \& Shacklock, K. (2012). Communication, training, well-being and commitment. Nursing Outlook, 60(1), 7-15. doi:

10.1016/j.outlook.2011.04.004 
Buchan, J. (2002). Global nursing shortages. British Medical Journal, 324(7340), 751752.

Byrne, B. M. (2010). Structural equation modeling with AMOS: Basic concepts, applications, and programming (2nd ed.). New York: Routledge.

Carmeli A, R Meitar and J Weisberg (2006) Self-leadership skills and innovative behaviour at work.International Journal of Manpower 27(1), 75-90.

Carrell, M. R., \& Dittrich, J. E. (1978). Equity theory: The recent literature, methodological considerations, and new directions. Academy of Management Review, 3(2), 202-210.

Carter, A. J. W. (2000). Sharing the burden: a study of teamwork and well-being in secondary health care teams. Sheffield, U.K.: University of Sheffield.

Carver, L., \& Candela, L. (2008). Attaining organizational commitment across different generations of nurses. Journal of Nursing Management, 16(8), 984-991. doi:10.1111/j.1365-2834.2008.00911.X

Chang, W. Y., Ma, J. C., Chiu, H. T., Lin, K. C., \& Lee, P. H. (2009). Job satisfaction and perceptions of quality of patient care, collaboration and teamwork in acute care hospitals. Journal of Advanced Nursing, 65(9), 1946-1955. doi: 10.1111/j.1365-2648.2009.05085.x

Colquitt, J. A., LePine, J. A., \& Noe, R. A. (2000). Toward an integrative theory of training motivation: a meta-analytic path analysis of 20 years of research. Journal of Applied Psychology, 85(5), 678-707. doi: 10.1037/00219010.85.5.678

Cox, K. B. (2001). The effects of unit morale and interpersonal relations on conflict in the nursing unit. Journal of Advanced Nursing, 35(1), 17-25. doi: 10.1046/j.1365-2648.2001.01819.x

Cox, K. B. (2003). The effects of intrapersonal, intragroup, and intergroup conflict on team performance effectiveness and work satisfaction. Nursing Administration Quarterly, 27(2), 153-163. Retreived from http://www.ncbi.nlm.nih.gov/pubmed/12765107

Cropanzano, R., Rupp, D. E., \& Byrne, Z. S. (2003). The relationship of emotional exhaustion to work attitudes, job performance, and organizational citizenship behaviors. Journal of Applied Psychology, 88(1), 160-169. doi: 10.1037/00219010.88.1.160

DeJoy, D. M., \& Wilson, M. G. (2003). Organizational health promotion: broadening the horizon of workplace health promotion. American Journal of Health Promotion, 17(5), 337-341. doi: http://dx.doi.org/10.4278/0890-1171-17.5.337

DeKeyser-Ganz, F., \& Torren, O. (2013). Israeli nurse practice environment characteristics, retention, and job satisfaction. Israel Journal of Health Policy Research, 3(7), 1-8.

Diener, E. (2000). Subjective well-being: The science of happiness and a proposal for a national index. American Psychologist, 55(1), 34-43. doi: 10.1037/0003066X.55.1.34

DiMeglio, K., Padula, C., Piatek, C., Korber, S., Barrett, A., Ducharme, M., ... \& Corry, K. (2005). Group Cohesion and Nurse Satisfaction: Examination of a TeamBuilding Approach. Journal of Nursing Administration, 35(3), 110-120. Duffield, C., Roche, M., O’Brien-Pallas, L., Catling-Paull, C., \& King, M. (2009). Staff satisfaction and retention and the role of the Nursing Unit Manager. Collegian, 16(1), 11-17.

Dysvik, A., \& Kuvaas, B. (2008). The relationship between perceived training opportunities, work motivation and employee outcomes. International Journal 
of Training and Development, 12(3), 138-157. doi: 10.1111/j.1468-

2419.2008.00301.x

Galende, J., \& de la Fuente, J. M. (2003). Internal factors determining a firm's innovative behaviour. Research Policy, 32(5), 715-736. doi: http://dx.doi.org/10.1016/S0048-7333(02)00082-3

Glaser, S. R., Zamanou, S., \& Hacker, K. (1987). Measuring and interpreting organizational culture. Management Communication Quarterly, 1(2), 173-198. doi: 10.1177/0893318987001002003

Gong, Y., Law, K. S., Chang, S., \& Xin, K. R. (2009). Human resources management and firm performance: The differential role of managerial affective and continuance commitment. Journal of applied Psychology, 94(1), 263-275.

Gould-Williams, J., \& Davies, F. (2005). Using social exchange theory to predict the effects of HRM practice on employee outcomes: An analysis of public sector workers. Public Management Review, 7(1), 1-24.

Gouldner, A. (1960). The norm of reciprocity: A preliminary statement. American Sociological Review, 25, 161-178.

Grant, A. M., Christianson, M. K., \& Price, R. H. (2007). Happiness, Health, or Relationships? Managerial Practices and Employee Well-Being Tradeoffs. The Academy of Management Perspectives, 21(3), 51-63. doi: 10.5465/AMP.2007.26421238

Guest, D. E. (2011). Human resource management and performance: still searching for some answers. Human Resource Management Journal, 21(1), 3-13.

Hair, J. F., Black, W. C., Babin, B. J., \& Anderson, R. E. (2010). Multivariate data analysis: A global perspective. Upper Saddle River, New Jersey: Pearson Education.

Hannah, D., \& Iverson, R. (2004). Employment relationships in context: Implications for policy and practice. In J. Coyle-Shapiro, L. Shore, S. Taylor \& L. Tetrick (Eds.), The employment relationship: Examining psychological and contextual perspectives (Vol. 332-350, pp. 350). Oxford: Oxford University Press.

Health Workforce Australia (2012). Health workforce 2025 - Doctors, nurses and midwives - Volume 1. Health Workforce Australia, Adelaide.

Hiltrop, J. M. (1996). A framework for diagnosing human resource management practices. European Management Journal, 14(3), 243-254.

Homans, G. C. (1974). Social behavior: Its elementary forms: New York: Harcourt.

Huhtala, H., \& Parzefall, M. R. (2007). A Review of Employee Well-Being and Innovativeness: An Opportunity for a Mutual Benefit. Creativity and Innovation Management, 16(3), 299-306. doi: 10.1111/j.1467-8691.2007.00442.x

Jiang, J., Wang, S., \& Zhao, S. (2012). Does HRM facilitate employee creativity and organizational innovation? A study of Chinese firms. International Journal of Human Resource Management, 23(19), 4025-4047

Jimenez-Jimenez, D., \& Sanz-Valle, R. (2005). Innovation and human resource management fit: an empirical study. International Journal of Manpower, 26(4), 364-381. doi: 10.1108/01437720510609555

Judeh, M. (2011). An examination of the effect of employee involvement on teamwork effectiveness: an empirical study. International Journal of Business and Management, 6(9), 202-209.

Kalisch, B. J., Hyunhwa, L. E. E., \& Rochman, M. (2010). Nursing staff teamwork and job satisfaction. Journal of Nursing Management, 18(8), 938-947. doi: 10.1111/j.1365-2834.2010.01153.x 
Kanter, R. M. (1996). When a thousand flowers bloom: Structural, collective, and social conditions for innovation in organization. . In P. S. Meyers (Ed.),

Entrepreneurship: the social science view (pp. 93-130). ButterworthHeinemann.

Katzenbach, J. R., \& Smith, D. K. (1993). The discipline of teams. Harvard Business Review, 71, 111-111. Retrieved from http://hbr.org/2005/07/the-discipline-ofteams/ar/1 17602399

Kirkpatrick, D. L. (1979). Techniques for evaluating training programs. In D. P. Ely \& T. Plomp (Eds.), Classic writings on instructional technology (Vol. 1, pp. 231241). Englewood, CO: Libraries Unlimited, Inc.

Kinnie, N., Hutchinson, S., Purcell, J., Rayton, B., \& Swart, J. (2005). Satisfaction with HR practices and commitment to the organisation: why one size does not fit all. Human Resource Management Journal, 15(4), 9-29. doi: 10.1111/j.17488583.2005.tb00293.x

Kline, R. B. (2011). Principles and practice of structural equation modeling. New York, NY: The Guilford Press.

Knol, J., \& van Linge, R. (2009). Innovative behaviour: the effect of structural and psychological empowerment on nurses. Journal of Advanced Nursing, 65(2), 359-370. doi: 10.1111/j.1365-2648.2008.04876.x

Kooij, D. T., Guest, D. E., Clinton, M., Knight, T., Jansen, P. G., \& Dikkers, J. S. (2013). How the impact of HR practices on employee well-being and performance changes with age. Human Resource Management Journal, 23(1), $18-35$.

Leggat, S. G. (2007). Effective healthcare teams require effective team members: defining teamwork competencies. BMC Health Services Research, 7(1), 17-27. doi:10.1186/1472-6963-7-17

Letvak, S., \& Buck, R. (2008). Factors Influencing Work Productivity and Intent to Stay in Nursing. Nursing Economics, 26(3), 159-165. Retrieved from http://www.ncbi.nlm.nih.gov/pubmed/18616053

Lim, B. C., \& Klein, K. J. (2006). Team mental models and team performance: A field study of the effects of team mental model similarity and accuracy. Journal of Organizational Behavior, 27(4), 403-418.

MacLean, L., Hassmiller, S., Shaffer, F., Rohrbaugh, K., Collier, T., \& Fairman, J. (2014). Scale, causes, and implications of the primary care nursing shortage. Annual review of public health, 35, 443-457.

MacKinnon, D. P., Lockwood, C. M., Hoffman, J. M., West, S. G., \& Sheets, V. (2002). A comparison of methods to test mediation and other intervening variable effects. Psychological methods, 7(1), 83-104. doi: 10.1037/1082-989X.7.1.83

MacKinnon, D. P., Lockwood, C. M., \& Williams, J. (2004). Confidence limits for the indirect effect: Distribution of the product and resampling methods. Multivariate Behavioral Research, 39(1), 99-128. doi:10.1207/s15327906mbr3901_4

Manser, T. (2008). Teamwork and patient safety in dynamic domains of healthcare: a review of the literature. Acta Anaesthesiologica Scandinavica, 53(2), 143-151. doi: 10.1111/j.1399-6576.2008.01717.x

Maqsood, T., Walker, D., \& Finegan, A. (2007). Facilitating knowledge pull to deliver innovation through knowledge management: a case study. Engineering, Construction and Architectural Management, 14(1), 94-109. doi: 10.1108/09699980710717007 
Martins, E., \& Terblanche, F. (2003). Building organisational culture that stimulates creativity and innovation. European Journal of Innovation Management, 6(1), 64-74.

Maskell-Pretz, M., \& Hopkins, W. E. (1997). Women in engineering: Toward a barrierfree work environment. Journal of Management in Engineering, 13(1), 32-37. doi: 10.1061/(ASCE)0742-597X(1997)13:1(32)

Maurer, T. J., \& Rafuse, N. E. (2001). Learning, not litigating: Managing employee development and avoiding claims of age discrimination. The Academy of Management Executive, 15(4), 110-121. doi: 10.5465/AME.2001.5898395

McCallin, M., \& Frankson, C. (2010). The role of the charge nurse manager: a descriptive exploratory study. Journal of Nursing Management, 18(3), 319-325. doi: 10.1111/j.1365-2834.2010.01067.x

McMurray, A. J., \& Williams, L. (2004). Factors impacting on nurse managers' ability to be innovative in a decentralized management structure. Journal of Nursing Management, 12(5), 348-353. doi: 10.1111/j.1365-2834.2004.00426.x

Meyer, J. P., \& Smith, C. A. (2000). HRM practices and organizational commitment: Test of a mediation model. Canadian Journal of Administrative Sciences, 17(4), 319-331. doi: 10.1111/j.1936-4490.2000.tb00231.x

Morrison, E. (1996). Organizational citizenship behavior as a critical link between HRM practices and service quality. Human Resource Management, 35, 493-512.

Myers, D. G., \& Diener, E. (1995). Who is happy? Psychological Science, 6(1), 10-19. doi: 10.1111/j.1467-9280.1995.tb00298.x

Naranjo-Valencia, J. C., Jiménez-Jiménez, D., \& Sanz-Valle, R. (2011). Innovation or imitation? The role of organizational culture. Management Decision, 49(1), 5572. doi: 10.1108/00251741111094437

Nelsey, L., \& Brownie, S. (2012). Effective leadership, teamwork and mentoring Essential elements in promoting generational cohesion in the nursing workforce and retaining nurses. Collegian, 19(4), 197-202. doi: http://dx.doi.org/10.1016/j.colegn.2012.03.002 (2008), pp. 11-17

Noblet, A. J., \& Rodwell, J. J. (2009). Integrating job stress and social exchange theories to predict employee strain in reformed public sector contexts. Journal of Public Administration Research and Theory, 19(3), 555-578.

OECD. (2006). Live Longer. Organisation for Economic Co-operation and Development, Paris.

Podsakoff, P. M., MacKenzie, S. B., Lee, J. Y., \& Podsakoff, N. P. (2003). Common method biases in behavioral research: a critical review of the literature and recommended remedies. Journal of Applied Psychology, 88(5), 879-903. doi: 10.1037/0021-9010.88.5.879

Reuvers, M., van Engen, M., Vinkenburg, C., \& Wilson-Evered, E. (2008). Transformational leadership and innovative work behaviour: exploring the relevance of gender differences. Creativity and Innovation Management, 17(3), 227-244. doi: 10.1111/j.1467-8691.2008.00487.x

Rubin, R. B., Palmgreen, P., Sypher, H. E., \& Beatty, M. J. (1994). Communication research measures: A sourcebook. New York: Guilford Press.

Sargeant, J., Loney, E., \& Murphy, G. (2008). Effective interprofessional teams: "Contact is not enough" to build a team. Journal of Continuing Education in the Health Professions, 28(4), 228-234.

Sanders, K., Moorkamp, M., Torka, N., Groeneveld, S., \& Groeneveld, C. (2010). How to Support Innovative Behaviour? The Role of LMX and Satisfaction with HR Practices. Technology \& Investment, 1(1), 57-66. doi:10.4236/ti.2010.11007 
Santos, A., \& Stuart, M. (2003). Employee perceptions and their influence on training effectiveness. Human Resource Management Journal, 13(1), 27-45. doi: 10.1111/j.1748-8583.2003.tb00082.x

Scott, S., \& Bruce, R. (1994). Determinants of innovative behaviour: a path model of individual innovation in the workplace. Academy of Management Journal, 37(3), 580-607. doi: 10.2307/256701

Scozzi M, C Carvelli and K Crowston (2005) Methods for modelling and supporting innovationprocesses in SMEs. European Journal of Innovation Management $8(1), 120-137$.

Shader, K., Broome, M. E., Broome, C. D., West, M. E., \& Nash, M. (2001). Factors influencing satisfaction and anticipated turnover for nurses in an academic medical center. Journal of Nursing Administration, 31(4), 210-216. Retrieved from http://www.ncbi.nlm.nih.gov/pubmed/11324334

Tannenbaum, S. I., Mathieu, J. E., Salas, E., \& Cannon-Bowers, J. A. (1991). Meeting trainees' expectations: The influence of training fulfillment on the development of commitment, self-efficacy, and motivation. Journal of Applied Psychology, 76(6), 759-769. doi: 10.1037/0021-9010.76.6.759

Tidd, J., \& Bessant, J. (2013). Managing innovation: integrating technological, market and organizational change (Fifth ed.). John Wiley \& Sons.

Toh, S. G., Ang, E., \& Devi, M. K. (2012). Systematic review on the relationship between the nursing shortage and job satisfaction, stress and burnout levels among nurses in oncology/haematology settings. International Journal of Evidence-based Healthcare, 10(2), 126-141.

Twigg, D., Duffield, C., Thompson, P. L., \& Rapley, P. (2010). The impact of nurses on patient morbidity and mortality-the need for a policy change in response to the nursing shortage. Australian Health Review, 34(3), 312-316. doi: 10.1071/AH08668

Van Dyne, L., Jehn, K. A., \& Cummings, A. (2002). Differential effects of strain on two forms of work performance: Individual employee sales and creativity. Journal of Organizational Behavior, 23(1), 57-74.

van Eijs, P., \& Heijke, H. (2000). Mismatch between occupation and education and the costs and benefits of job-related training. In H. Heijke \& J. Muysken (Eds.), Education and Training in a Knowledge-Based Economy (pp. 159-189). London: MacMillan.

van Mierlo, H., Rutte, C. G., Kompier, M. A. J., \& Doorewaard, H. A. C. M. (2005). Self-Managing Teamwork and Psychological Well-Being Review of a Multilevel Research Domain. Group \& Organization Management, 30(2), 211235. doi: $10.1177 / 1059601103257989$

van Mierlo, H., Rutte, C. G., Seinen, B., \& Kompier, M. (2001). Autonomous teamwork and psychological well-being. European Journal of Work and Organizational Psychology, 10(3), 291-301. doi:10.1080/13594320143000681

Veenendaal, A., \& Bondarouk, T. (2015). Perceptions of HRM and their effect on dimensions of innovative work behaviour: Evidence from a manufacturing firm. Management Revue, 26(2), 138-160. doi: 10.1688/mrev-2015-02-Veenendaal

Wallin, L., \& Wright, I. (1986). Psychosocial aspects of the work environment: A group approach. Journal of Occupational and Environmental Medicine, 28(5), 384393. Retrieved from http://www.ncbi.nlm.nih.gov/pubmed/3712118

West, M. A., \& Farr, J. L. (1990). Innovation at Work. In M. A. West \& J. L. Farr (Eds.), Innovation and creativity at work: Psychological and organizational strategies (pp. 3-13). Chichester: Wiley. 
West, M. A., \& Wallace, M. (1991). Innovation in health care teams. European Journal of Social Psychology, 21(4), 303-315. doi: 10.1002/ejsp.2420210404

Wood, S., \& de Menezes, L. M. (2011). High involvement management, highperformance work systems and well-being. The International Journal of Human Resource Management, 22(07), 1586-1610. doi:10.1080/09585192.2011.561967

Wright, T. A., Cropanzano, R., \& Bonett, D. G. (2007). The moderating role of employee positive well being on the relation between job satisfaction and job performance. Journal of Occupational Health Psychology, 12(2), 93-104. doi: 10.1037/1076-8998.12.2.93

Wright, T. A., \& Walton, A. P. (2003). Affect, psychological well-being and creativity: Results of a field study. Journal of Business and Management, 9(1), 21-32.

Xerri, M. J. (2014). Examining The Relationship Between Organisational Justice, Job Satisfaction and The Innovative Behaviour of Nursing Employees. International Journal of Innovation Management, 18(01), 1-22.

Xerri, M., \& Brunetto, Y. (2011). Fostering the innovative behaviour of SME employees: a Social Capital perspective. Research and Practice in Human Resource Management, 19(2), 43-59. Retrieved from http://rphrm.curtin.edu.au/2011/issue2/index.html

Xerri, M. J., \& Brunetto, Y. (2013). Fostering innovative behaviour: the importance of employee commitment and organisational citizenship behaviour. The International Journal of Human Resource Management, 24(16), 3163-3177. doi:10.1080/09585192.2013.775033

Zhou, Y., Zhang, Y., \& Montoro-Sánchez, Á. (2011). Utilitarianism or romanticism: the effect of rewards on employees' innovative behaviour. International Journal of Manpower, 32(1), 81-98. doi: 10.1108/01437721111121242 
Table 1. Composite reliability, AVE and correlations: Private sector sample

\begin{tabular}{|c|c|c|c|c|c|c|}
\hline Variables & $\begin{array}{l}\text { Composite } \\
\text { Reliability }\end{array}$ & AVE & 1 & 2 & 3 & \\
\hline Innovative behaviour & .78 & .57 & $(.75)$ & & & \\
\hline Wellbeing & .84 & .65 & $.254 * *$ & $(.81)$ & \\
\hline $\begin{array}{l}\text { Satisfaction with } \\
\text { teamwork }\end{array}$ & .87 & .65 & $.249 * *$ & $.363 * *$ & \multicolumn{2}{|c|}{$(.81)$} \\
\hline $\begin{array}{l}\text { Satisfaction with } \\
\text { training opportunities }\end{array}$ & .87 & .63 & $.214 * *$ & $.566^{* *}$ & \multicolumn{2}{|c|}{$.389 * *$} \\
\hline Gender & - & - & .039 & -.011 & \multicolumn{2}{|c|}{.000} \\
\hline Education & - & - & -.122 & -.128 & \multicolumn{2}{|c|}{-.090} \\
\hline \multicolumn{7}{|c|}{$\begin{array}{l}\text { Diagonal elements in the parentheses are the square root of the average variance extracted (AVE). } \\
* * \text {. Correlation is significant at the } 0.01 \text { level ( } 2 \text {-tailed). }\end{array}$} \\
\hline Table 2. ANOVA of & \multicolumn{2}{|c|}{ Private $^{\mathrm{a}}$} & \multicolumn{2}{|c|}{ Public $^{\mathrm{b}}$} & & \\
\hline Variable & Mean* & SD & Mean* & SD & $\mathbf{F}$ & Sig. \\
\hline Innovative behaviour & 4.30 & 1.07 & 4.34 & 1.08 & .000 & .983 \\
\hline Wellbeing & 4.34 & .99 & 4.35 & 1.00 & .002 & .972 \\
\hline $\begin{array}{l}\text { Satisfaction with } \\
\text { teamwork }\end{array}$ & 4.32 & .69 & 4.32 & .69 & .001 & .968 \\
\hline $\begin{array}{l}\text { Satisfaction with } \\
\text { training opportunities }\end{array}$ & 4.19 & .72 & 4.18 & .73 & .003 & .958 \\
\hline
\end{tabular}

Table 3: Confirmatory factor analysis - examining goodness-of-fit

\begin{tabular}{lllll}
\hline & CMIN/ & CFI & TLI & RMSEA \\
& DF & & & \\
\hline Hypothesised measurement model & 1.89 & .935 & .926 & .055 \\
Modified measurement model & 1.62 & .956 & .950 & .045 \\
$\begin{array}{l}\text { Model 1: partial mediation between teamwork and } \\
\text { innovative behaviour }\end{array}$ & 1.64 & .955 & .949 & .045 \\
Model 2: partial mediation between training & & & & \\
opportunities and innovative behaviour & 1.63 & .956 & .949 & .045 \\
Model 3: full mediation model & & & & \\
Model 4: Adds common latent factor to Model 3 & 1.62 & .956 & .950 & .045 \\
& 1.42 & .974 & .967 & .040 \\
\hline
\end{tabular}

Table 4: Testing mediation

\begin{tabular}{llcl}
\hline Relationship & Total effect & Direct effect & $\begin{array}{l}\text { Indirect } \\
\text { effects }\end{array}$ \\
\hline $\begin{array}{l}\text { H6: wellbeing mediates satisfaction with } \\
\text { teamwork } \rightarrow \text { innovative behaviour }\end{array}$ & $.311(\mathrm{P}<.01)$ & $.216(\mathrm{P}<.05)$ & $.095(\mathrm{P}<.05)$ \\
$\begin{array}{l}\text { H7: wellbeing mediates satisfaction with } \\
\text { training opportunities } \rightarrow \text { innovative } \\
\text { behaviour }\end{array}$ & $.177(\mathrm{P}<.05)$ & $.068(\mathrm{P}>.05)$ & $.109(\mathrm{P}<.05)$ \\
\hline
\end{tabular}




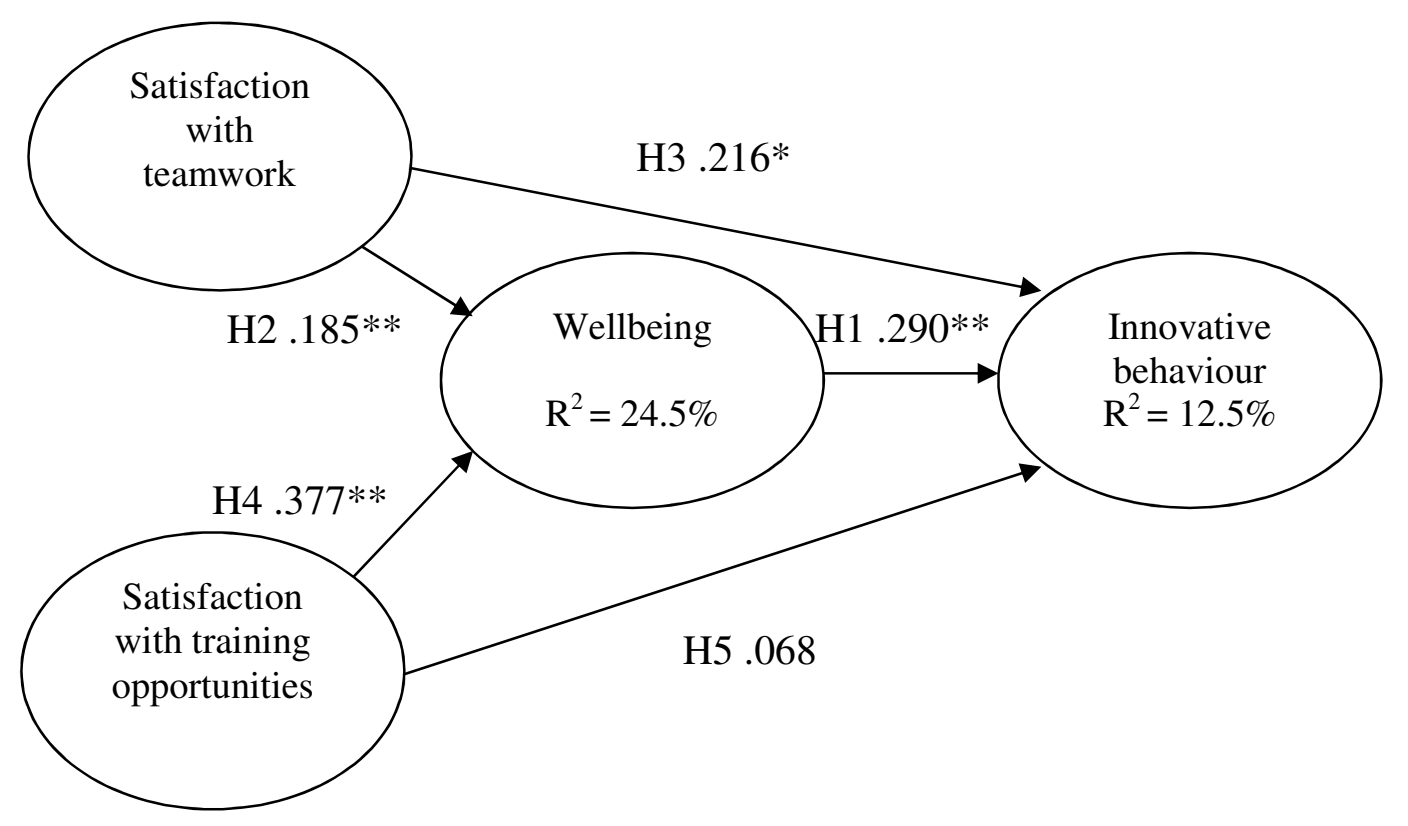

Figure 1. Standardised parameter estimates

Note: $* \mathrm{p}<.05, * * \mathrm{p}<.01, * * * \mathrm{p}<.001$ 